\title{
Autosomal Dominant Osteopetrosis
}

National Cancer Institute

\section{Source}

National Cancer Institute. Autosomal Dominant Osteopetrosis. NCI Thesaurus. Code C129732.

An autosomal dominant form of osteopetrosis due to mutation(s) in the CLCN7 gene, encoding $\mathrm{H}(+) / C \mathrm{Cl}(-)$ exchange transporter 7 . Clinical features include sclerosis involving the spine, the pelvis, and the base of the skull. Complications can include optic nerve compression, dental abscesses, anemia, and bone fragility. One third of individuals who carry a CLCN7 mutation have a normal skeletal phenotype. 